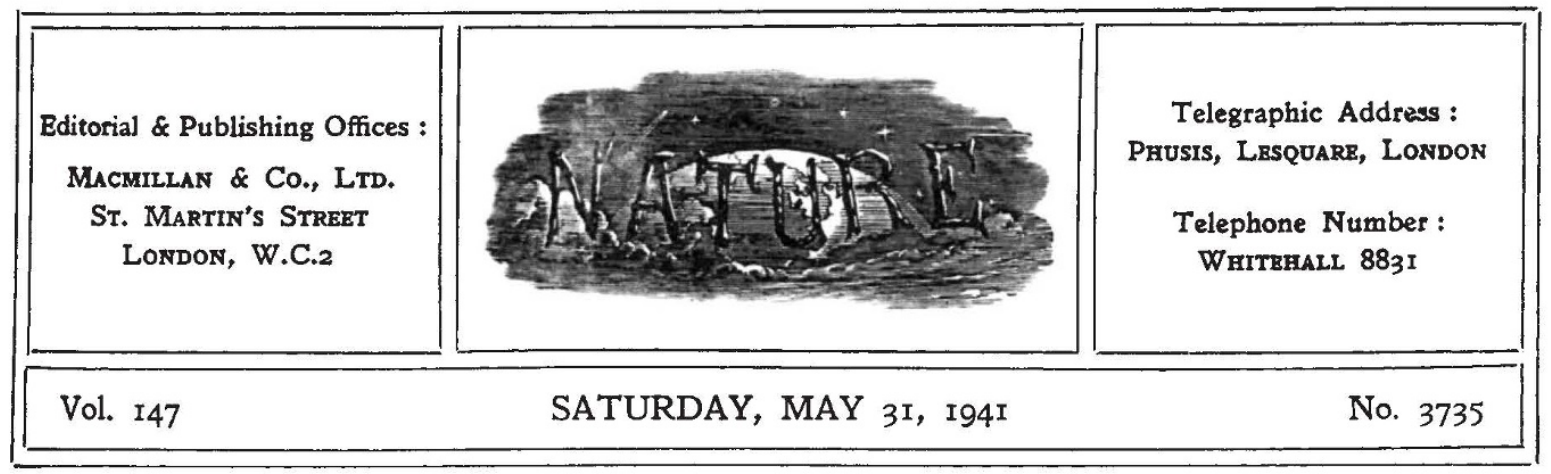

\title{
RECONSTRUCTION AND PLANNING
}

A NOTEWORTHY illustration of the strength of the national morale is the widespread interest taken in post-War reconstruction. The immediate task of the Ministry of Works and Buildings in speeding up the erection of buildings needed for the war effort is generally taken for granted. It is the contribution of the Ministry to the building of the world we shall live in after the War that captures the popular imagination.

It is somewhat surprising, therefore, that so little attention has been given in the Press to the Conference on National Planning held by the Garden Cities and Town Planning Association at 0xford on March 28--30. However much it may be necessary to postpone the physical reconstruction until after the War, it is essential that the principles upon which our policy is to be based and by which action is to be guided should be elucidated and defined as early as possible, even if only in view of their bearing on the wise direction of our war effort-as, indeed, the Select Committee on National Expenditure has hinted. A summary account of some of the papers appears on $p 684$ of this issue of NATURE.

Research is equally important on particular questions and on those involving general policy and principles. This point was well made by Major E. Maxwell Fry in a recent address to the Housing Centre on "Research on a Plan for London". A town-planning scheme must be the result of research into the elements of living, which must be organized in the most efficient manner. The problem in London is concentrated in the provision of good housing, opportunities for adequate leisure and healthy work-places, linked together by efficient transport services. These four elements-work, leisure, housing and trans- port-are interdependent and form the basis of the problem.

Investigation on the general and on the particular questions must clearly proceed simultaneously if we are to be prepared when the full opportunities arise after the War. Moreover, there are matters in which action may be required during the War to prevent the growth of further obstacles to central development and effective local planning. To some of these attention was directed by Sir Ernest Simon in a paper before the Conference on National Planning on urban landownership and management after the War, and Lord Samuel, in a reference to the same subject, welcomed a statement in the House of Lords by Lord Brocket, chairman of the Land Union, that the Union is ready to welcome reasonably devised measures for bringing the use of the land into conformity with the interests of the nation. To problems such as compensation and betterment the Uthwatt Committee is already giving attention, and it may well be hoped that Lord Reith will take action in time to prevent private interests in the devastated districts or elsewhere creating obstacles to developments required in the public interest.

The further attention directed to these matters by the Conference on National Planning is warmly to be welcomed, and the fresh support forthcoming for national planning should at least lead to fuller consideration of the recommendations of the Royal Commission on the Location of Industry.

There are undoubtedly limitations on the extent to which effort can be expended in these directions during war-time. It is all the more important, therefore, that the more restricted opportunities should not be missed. The discussions at Oxford 
are supplemented by Mr. Ritchie Calder in his Democratic Order Pamphlet No. 5, the theme of which is that we should start planning Britain now. The essential thing is that, as Mr. W. H. Ansell, president of the Royal Institute of British Architects, urged in his paper on "The London of the Future" before the Royal Society of Arts on March 12, we should clarify our general principles and think about those principles before proceeding to particular planning. Too often in the past the thinking has followed the planning, or rather the lack of planning. The immediate urgency is the preparation of the plan in order that when peace comes upon us, it shall not find us unready, and in consequence rebuilding of our cities and factories take undesirable forms.

Mr. Ansell's paper alone is an inspiring picture of possibilities in the planning and rebuilding of London-the redistribution of industries, the re-planning of traffic, of docks and markets, the restoration to the City of something of the glory lost by its congestion, the preservation and encouragement of community areas or the creation of new ones, the re-planning of commercial areas and the architectural opportunities in scientific and fire-resisting reconstruction-possibilities which in varying degrees are inherent in the planning and reconstruction anywhere necessitated by devastation through bombing. The vision of possibilities, when fortified by the determination to use our opportunities, can supply steadiness in the dark days of ordeal which may yet lie ahead, and the stimulus to co-operation in the work of reconstruction, with something of the national unity and energy at present displayed in our war effort.

Several aspects of planning are referred to in two Democratic Order series of pamphlets referred to below*. Mr. Calder ranges concisely over the whole field, indicating mistakes and confusion in the past, the present position, not merely of the Ministry of Works and Buildings, but also of planning and location of industry as resulting from the Barlow Commission inquiry, the weakness of local and regional authorities, and the opportunities and problems which have already been thrown up by the War. With many of these scientific workers are familiar, but Mr. Calder surveys them with a lucidity which should bring home to every citizen the vital need for some definite policy and national planning.

* The Democratic Order. No. 1: What are we waiting for?: a Call to Britain. By Francis Williams. Pp.64. No.5: Start Planning Britain Now : a Policy for Reconstruction. By Ritchie Ca
(London : Kegan Paul and Co., Ltd., 1941.). 18. net each.
Mr. Calder shows, too, how this question of planning and reconstruction is linked up with the development of social services, particularly with questions of nutrition and medical service, and the tremendous demands it makes on the intelligent use of our resources on scientific lines, whether in such matters as standardization, transport, or the interlocking of agricultural and other industries food policy and nutrition, and the effect of changes in the age structure of our population upon housing and educational needs and policy. National planning is, in fact, more than the peace aim on which Mr. Calder insists. It is a vital part of our war effort and one of the ways in which we can, as Mr. Francis Williams argues, in "What are we waiting for?", make democracy not only something to fight for but something to fight with. A determined effort to deal now with the question of planning and all that is involved in working out the lines of policy, not just for physical reconstruction but also for the social and economic reconstruction needed, would give us a most effective weapon for the overthrow of the slavery masquerading throughout the greater part of Europe as the Nazi "New Order".

There are indeed welcome signs that this is increasingly recognized by the Government itself. The whole tenor of Lord Reith's recent statement in the House of Lords was coloured by the assumption that the principle of planning would be accepted as national policy, and that a central planning authority would be established. He has shown himself, further, to possess large and comprehensive views and to be alive to the need for further investigation. The examination of conditions in Birmingham, Coventry and Bristol and the whole. hearted support given to the work of the National Buildings Record are sufficient example. The personnel of the Consultative Panel on Reconstruction already announced by Lord Reith has commanded widespread approval; indeed, the chief concern at the present moment is that whatever plans are finally accepted should be consistent with the principles that administrative control should not be divided and that the planning authority should have power to put its policy into effect.

This is the main argument of two admirable articles which have recently appeared, one entitled "Problems of Reconstruction. I. Building", in the Round Table of March, and the other by Mr. Thomas Sharp on "Planning for Reconstruction" in the Political Quarterly of April-June. Botk 
point to the dangers inherent in the large number of Government departments concerned and the imperative need for co-ordination and for the handling of the main groups of problems by specially constituted ministries or sub-ministries, untrammelled by departmentalism. Lord Reith's own Ministry of Works and Buildings is the only example so far of the kind of special department required, and whether or not the present Ministry is expanded into a Ministry of Planning and takes over other functions from the Ministry of Health, War-time Communications, Agriculture, the Central Electricity Board, the Forestry Commissioners, the "National Industrial Board" recommended by the Barlow Commission and the National Park Commission recommended by the National Parks Committee, if the present opportunity is to be used some authority must be given power to plan all post-war land now, and to initiate the bold measures which will make possible the successful execution of a post-war building programme embodying the new approach to social problems involved in the planning of a new and better society.

A scheme suggested in the Round Table visualizes the Ministry of Works and Buildings as supreme authority and including four distinct sections. The first of these is the lineal descendant, much expanded, of His Majesty's Office of Works, which, among other functions, might exercise the required control over building and stimulate the far-sighted statesmanship on the side of employers and trade unions required in planning boldly several years ahead. The sccond is a long-term planning organization concerned with the location of industry and with town and country planning, exercising many of the functions recommended in the Minority Report of the Barlow Commission, including the functions and powers transferred from the Ministry of Health, the former Ministry of Transport and the Commissioners for the Special Areas. This division would co-ordinate the long-term building projects so that too much is not attempted in any one year, but the detailed planning and execution of the building programme of the whole country, both civil and Governmental, would be entrusted to a programme department. Both these departments would work in close contact with a National Investment Board and the National Housing Board.

Besides these three divisions, a housing division is suggested which would take over most of the present housing functions of the Ministry of Health and supervise housing finance through the National
Housing Board. The latter would be a purely financial institution, the nucleus of which might well be formed by the building societies; but by accepting responsibilities of landlordship, it would be able to compel builders to accept high-standards of design and workmanship. The division would supervise the quality of the houses built and enter into direct relations with the local authorities in respect of the programmes carried out by them.

A centralized plan of this character does not mean the imposition of local building programmes from above. Only national requirements should be planned at the centre. Regional and local details within the national plan should be planned regionally through a series of regional planning commissions, but some one department must deal with all land-using activities if the waste of land and its misdirection from the purpose which best serves the public interest, whether by the speculative builder, the industrialist or the Forestry Commissioners, is to be stopped. Administrative power in a democracy must remain in close contact with the people, their welfare and their desires.

These thoughtful articles are no less insistent than Mr. Francis Williams, in his lively and provocative "What are we waiting for?", that the start on such planning must be made now, and that we must not allow the attempt to be hampered by the professional tradition or outlook of the Civil Service. Nor need we despair, even with the present demand for man-power, of allocating a proportion to prepare us to meet post-War problems. Obviously some thought is already being given to these matters by the Government. Regional geographers, sociologists, economists, architects and town-planners may be reasonably expected to pay attention to these problems even in war-time.

There should indeed be no insuperable obstacles to the marshalling at the present moment of an effective proportion of the trained intelligence of the nation to the formulation of policy and plans to prevent hindrances to reconstruction developing during the War, as well as scramble, confusion and improvised plans and decisions to meet demands for action which will urgently and insistently arise when the War ends. Only by foresight, coupled with constructive imagination, clear thinking and unflinching loyalty to sound administrative principles throughout the present days of war, can we ensure an adequate recompense after the War for all the sufferings and hardship we have already faced or may still be called upon to endure. 